\title{
L2 KNOWLEDGE FACILITATING L3 LEARNING: THE ROLE OF RUSSIAN LINGUISTIC FACTORS IN UNDERSTANDING OF UKRAINIAN BY ESTONIANS
}

\author{
Anna Branets \\ University of Tartu
}

\section{Ad Backus}

Tilburg University

\begin{abstract}
This paper reports on an empirical investigation of how knowledge of L2 Russian can facilitate the acquisition of passive knowledge of L3 Ukrainian by speakers of L1 Estonian. The experiment was conducted with 30 speakers of Estonian as L1, who first filled in a sociolinguistic questionnaire, then completed a C-test in their L2 Russian, before carrying out a task testing their understanding of L3 Ukrainian words and texts, and providing some feedback in a debriefing session. We pay specific attention to the performance on the Russian C-test and how participants' scores correlate with their results on the Ukrainian tasks. We also made an inventory of the grammatical and lexical elements that proved easy or difficult. The results show a positive correlation between the scores on the C-test and performance on the Ukrainian tasks. However, this correlation was lower for text understanding in Ukrainian than for understanding separate Ukrainian words. This suggests that a C-test score does not predict participants' ability to understand the Ukrainian texts to a full extent, while it has better predictive value for the understanding of individual Ukrainian words. These findings suggest that learners use resources beyond just L2 lexical-grammatical knowledge in forming an understanding of texts in an L3 that is closely related to the L2.
\end{abstract}

Keywords: mediated receptive multilingualism, comprehension, L3 language acquisition, C-test, Ukrainian, Russian, Estonian 


\section{Introduction}

One of the effects of globalization is that people around the world increasingly find that their linguistic resources are not sufficient to meet life's demands. As people move around the world, they often face the task of having to learn a new language, or at least learn it well enough to get by. Some need to function professionally in an L2 environment, for example, or need to be able to function informally in an L2 environment in which English is used professionally but the local language is used for everything else, etc. Similarity between L1 and L2 has been shown to facilitate L2 learning (Odlin 1989), and the same is claimed to hold for the relation between L2 and L3 (Bardel, Falk 2007; Flynn et al. 2004). While an L3 may be very different from the mother tongue, speakers may have learned an L2 that is closer to the new language. This is the case for example for someone who needs to learn English and has already learned German, or, as we will examine in this study, for an Estonian speaker who has to learn Ukrainian and already knows Russian. The similarities between Ukrainian and Russian will provide useful scaffolding for learning Ukrainian words and structures as they both belong to the East Slavic language family.

While previous work has shown that knowing a closely related L2 positively influences L3 acquisition (Bardel, Falk 2007; Flynn et al. 2004), many aspects of this facilitation need illuminating, since knowing a language involves many different kinds of knowledge, from the purely linguistic, such as pronunciation, words and grammar rules, to the pragmatic and cultural, such as how to infer intended meanings, when to say what and how, and how to co-create communication in which interlocutors help each other achieve understanding. Pronunciation, vocabulary and grammar tend to hold privileged positions in language teaching settings, an importance reflected by the importance they are accorded in proficiency tests, but it may be that this comes at the expense of other skills. Having previous experience in multilingual environments, for example, 
may equip one with communicative resources for learning how to overcome the consequences of limited fluency. Interlocutors may, for example, help each other negotiate the meanings of unfamiliar words, they may engage in codeswitching where useful, or they may encourage each other to use their respective mother tongues (a pattern known as 'Receptive Multilingualism'; Rehbein et al. 2011). In this study, we investigate whether Estonian speakers' Russian vocabulary and grammar knowledge, as tested with a traditional proficiency test, impacts their general understanding of Ukrainian texts as much as it does their recognition of Ukrainian words. None of the participants had previous experience with Ukrainian.

Estonian (Finnic, Uralic) and Ukrainian (East-Slavic, IndoEuropean) are not related, nor is there a bilingual community that speaks these languages, but many speakers of Estonian have knowledge of Russian. The two languages of Ukrainian and Russian have similar syntactic structures, and $62 \%$ similarity in lexical composition (Tyshchenko 2010: 66). In this study we report on an experimental investigation with 30 Estonian participants who completed a C-test in Russian (Grotjahn 1987), followed by a test on individual Ukrainian words (Shumarova 2000) and one on a connected Ukrainian text (Gooskens 2013). In a debriefing session, participants were also invited to provide feedback on their experience. Prior to the experiment, participants filled in a sociolinguistic questionnaire on language use and attitudes. The participants are speakers of Estonian as L1. The experiment is a part of a larger study discussed in Branets, Bahtina and Verschik (2019). The aims of this paper are to verify whether the participants' performance on the C-test in Russian indeed predicted their results on the two Ukrainian tasks, and to see which aspects of Russian turned out to be difficult for the participants, and therefore unlikely to be of much help in understanding Ukrainian. The paper is organized as follows: first, we discuss previous work on L3 learning, then we report on the experimental design of the study, and this is followed by the results and a general discussion. 


\section{L3 learning facilitated by L2 knowledge}

Studies of third language (L3) acquisition have shown evidence for the positive influence of an L2 on the acquisition of an L3 (Cenoz, Genesee 1998; Cenoz, Jessner 2000; Cenoz 2001, 2003; Leung 2005). Flynn et al. (2004) and Cenoz (2003) state that typological proximity is a significant facilitator of positive transfer in language acquisition: the closer the L2 is to the target L3 the more structures are transferred from L2 to L3. Ringbom (1987) and Hammarberg (2001) pointed out proficiency as an influential factor: the lower the proficiency in L3, the more it will be affected by L2, echoing what is found for transfer in L2 acquisition. In the transfer, learners establish relations between units of the target language and their L1 or L2 (Ringbom, Jarvis 2009). The more linguistic cues that can be established between L2 and L3, the better understanding of L3 can be achieved.

In addition to developing linguistic competence (phonology, vocabulary and syntax), becoming communicatively competent in a language also requires learning ways of pragmatically using the language (Oller 1970, Fisher 1984, Harmer 2001). Successful communication can take place even if interlocutors have limited linguistic competence, especially if they can make skilled use of communicative strategies (Firth, Wagner 2007: 296). Good learners are argued to be able to combine knowledge of the rules of formal syntactic, morphological, phonological and lexical systems with knowledge of the rules or conventions for their use (Long 1981: 275; Block 2003: 61). This becomes especially important when the goal of language learning is not to achieve a good score on a classroom assessment but to be able to communicate in everyday settings. In fact, language learning often proceeds without formal instruction, and thus without explicit lessons on formal grammar and vocabulary. It is unclear to what extent gaining strictly linguistic knowledge facilitates the acquisition of communicative competence more generally.

Applying second language knowledge in informal interaction, and the specific challenges this involves, captivated the attention 
of second language acquisition (SLA) researchers early on (Alcón, Usó 1998; Brouwer, Wagner 2004; Eskildsen 2019; Firth, Wagner 1997; Long 1981; Wagner 2004). 'Incidental' learning has also been investigated in SLA research that focuses on how linguistic items are learned in interaction (Brouwer et al. 2004, Brouwer 2003). Accordingly, language testing regimes use 'can do' scales to measure proficiency (e.g. the Common European Framework of Reference), which have the advantage of acknowledging the importance of communicative skills, but lack the precision associated with the vocabulary and grammar tests that are still widely used as well, perhaps for that very reason. The current article does not directly contribute to the development of tests for communicative competence, but we do investigate how well the ability to achieve general understanding of text in a foreign language correlates with knowledge of words and grammar. If it does, this would suggest that traditional proficiency tests are a good proxy for general communicative proficiency. However, we will see that our results call for caution in this respect.

We will address these issues specifically in a situation of incipient L3 learning. Learning an L3 is increasingly common in today's globalized world. Often, the desired ability is not necessarily to converse fluently in the foreign language but to be able to at least achieve sufficient understanding in order to follow a conversation or read a text. This mode of using a passively mastered language is known as Receptive Multilingualism and for various reasons, such as efficiency or fairness, it may be a preferred language choice pattern in specific settings. The phenomenon of reaching understanding in an L3 through the medium of an L2 has been investigated in constellations of typologically related languages, for instance, DutchGerman-Danish (Swarte et al. 2013) or Czech-Polish-Slovak-Sorbian (Sloboda, Brankačkec 2014). Our study builds on this tradition, but concerns a situation in which the L1 is unrelated to L2 and L3.

It is important to point out that our study is experimental: our participants were not actually engaged in learning L3 Ukrainian. 
We merely exposed them to the language for the first time, to see how their performance differs from the zero knowledge one would expect if they really had to start from scratch (i.e. without knowledge of Russian). For Estonians with knowledge of Russian, many of the words encountered in a Ukrainian text will immediately activate knowledge of cognates in Russian. Similarly, the order in which words appear as well as their general appearance, with various kinds of grammatical markers affixed to stems, will resemble patterns they are familiar with from Russian, and the expectation is that this knowledge is immediately activated to form hypotheses about what the Ukrainian words and sentences may mean. If their knowledge of Russian is shown to indeed facilitate substantial understanding of Ukrainian without any previous exposure, this would point to the potential of Receptive Multilingualism even when it is mediated through an actually mastered L2.

An earlier study (Branets et al. 2019) reported that in experimental settings participants (ethnic Russians from Russia who recently have moved to Estonia, local Russians with Russian as L1 and Estonian as L2, simultaneous/early Estonian-Russian bilinguals and speakers of Estonian as L1 with B1 and B2 proficiency in Russian) were indeed quite successful in understanding Ukrainian without previous exposure. Interestingly, participants who reported less advanced knowledge of Russian e.g. Estonian-Russian bilinguals and speakers of Estonian as L1 with B1 and B2 proficiency in Russian often tried harder and were more motivated, and this actually compensated for the more limited potential for positive transfer. However, this does not mean that the participants enjoyed only negligible amounts of positive transfer. The current paper focuses on the degree to which Russian proficiency as measured with a traditional test that privileges vocabulary and grammar predicts the participants' ability to perform two different aspects of foreign language performance: to recognize Ukrainian vocabulary, and to get the gist of Ukrainian texts. Given the overwhelming evidence for positive transfer in previous literature, we should expect positive 
correlations in both cases. If it is true that learners utilize the support of more than just available vocabulary and grammar knowledge to achieve general understanding, the correlation with the C-test results should be stronger for the word recognition task than for the general understanding test.

The rationale underlying the assumed facilitatory effect of L2 knowledge is that things known in the L2 are useful in learning the new language as long as they have similar counterparts in the L3. To understand why particular aspects of Ukrainian may present problems we analysed qualitatively what errors were made on the C-test so as to better understand the aspects of Russian that are problematic for Estonian speakers, and therefore will be of little use in understanding Ukrainian.

\section{Method and participants}

\section{I. APPROACH}

The experiment consisted of a socio-linguistic questionnaire (Bahtina-Jantsikene 2013), a C-test (Grotjahn 1987), tasks testing the understanding of Ukrainian words (Shumarova 2000) and of Ukrainian text as a whole (Gooskens 2013), and a debriefing session also used to collect participants' comments about their choices. The experiment is part of a larger study, presented in Branets et al. (2019).

The questionnaire was based on one used in Bahtina-Jantsikene (2013). It comprises 16 questions, and was used to document the sociolinguistic background of participants (age, gender, place of birth, place of residence, etc.), their degree of exposure to Russian and Ukrainian, and their language attitudes towards Ukrainian.

The C-test was developed according to the instructions of Grotjahn (1987). C-tests are usually used to measure proficiency in a first or second language. They allow precise assessment of grammar, vocabulary and overall reading comprehension (Chapelle 1994, Baghaei 2011). In our study, we used the C-test to measure the Russian grammatical and lexical proficiency of the participants. In 
order to choose four reliable texts, we piloted eight texts, selected from various magazines and newspapers, and ran them online on 11 speakers of Russian as L1 and 11 speakers of Russian as L2. The L1 and L2 speakers are all highly educated, and the L2 speakers had proficiency levels from B1 to $\mathrm{C} 1$ level. Participants were recruited either from Russian language courses at university level or had certificates attesting B1 to C1 level of proficiency.

Considering the fact that the participants in the main experiment would be similar to the L2 speakers in the pilot, we analysed the pilot results to see which items turned out to be more difficult for the L2 speakers (we discuss the results in Section 4.1).

Our eventual C-test consisted of the four short texts that had received the best scores from the L2 speakers. The second half of every second word in a sentence, starting from the second sentence, was missing (following Grotjahn's (1987) instructions). The texts comprised five or six sentences of the following types: simple, compound with an independent and a dependent clause, and one compound-complex sentence with two independent and two dependent clauses. The topics were an island in Italy, a story about the Chinese wall, prenuptial agreements, and travelling. The participants were asked to fill in the gaps using correct words and grammatical forms. Each text had 20 gaps, and participants were given five minutes to complete it. Their performance was evaluated according to the flexible scoring system from Bahtina-Jantsikene (2013: 28):

- 1 point: a fully correct answer (e.g., when a participant answered that боль... bol'... corresponds to большой bol'shoi 'big');

- 0.75 points: a correct yet grammatically or semantically imperfect answer, or a near synonym that matches the context ( ${ }^{\star}$ любов liubov for любовь liubov' 'love');

- 0.5 points: a misspelled word, only approximating the target (e.g., * nymешествоватся puteshestvovatsia for nymemecmвовать puteshestvovat' 'to travel'); 
- 0.25 points: a semantically related but grammatically or contextually incorrect (e.g., ${ }^{*}$ иущение imuschenie for имyщество imuschestvo 'property');

- 0 points: an unrelated word or no answer ( ${ }^{*}$ заль zaly 'halls' for залив zaliv 'gulf').

We conducted the C-tests manually with the participants right before they completed the Ukrainian tasks. The total number of test items was 80 (20 words per text and four texts in total).

After completing the C-test in Russian, the participants were given three Ukrainian texts to test their comprehension in Ukrainian. Each text was accompanied by a word-definition task to see whether they understood particular words from the text (Shumarova 2000) and questions to assess overall understanding (Gooskens 2013). The Ukrainian texts were given one by one and participants had to first read a text, then complete the assignments that accompanied it, and then do the same with the next text. They were allowed to read the text as many times as they wanted. The word definition task comprised 55 words from the texts: 36 that have cognates in Russian with the same meaning, 12 that have cognates with different meanings or that belong to different registers, and seven without cognates in Russian. Participants had to translate Ukrainian words into the language they were comfortable with or to write an answer in their own words. The following scoring system was applied (also outlined in Branets, Verschik accepted):

- 1 point: an entirely correct answer (e.g., when a participant recognizes that Ukrainian донька don'ka 'daughter' is the translation of Estonian tütar 'daughter', etc.)

- 0.75 points: a correct definition presented in an incorrect grammatical form (e.g., юнаки junaky 'young men, youth' (plural) translated as noormees 'young man' (singular) instead of noormehed 'young men, youth' (plural), etc.)

- 0.5 points: almost correct meaning (e.g., ніяк niyak 'by no means' translated as Estonian kuidagi 'somehow' instead of correct mitte kuidagi 'by no means') 
- 0.25 points: a semantically related lexeme that fits the context but is incorrect (e.g., Ukrainian заnumas zapytav 'asked' translated as Estonian ütles 'said')

- 0 points: a completely wrong answer (e.g., Ukrainian ревнощі revnoschi 'jealousy' translated as Estonian põhjustel 'reasons') or no answer.

The tasks for general understanding consisted of 15 true or false questions ( 1 - correct answer; 0 - incorrect), 15 multiple choice questions with three alternatives including one correct answer (1 correct; 0 - incorrect), and 6 open questions ( 1 - full answer; 0.75 partial answer; 0.5 - many details left out; 0.25 - relevant but some incongruence with context; 0 - false or no answer) (Branets et al. 2019: 11).

During the debriefing, which immediately followed the completion of all the aforementioned tasks, the participants were interviewed in order to collect their explanations of their answers and the strategies they used. The duration of each interview was 10-20 minutes. The whole experiment was conducted individually with each participant with pen and paper and took about two hours.

\subsection{PARTICIPANTS}

The experiment was conducted in Tallinn in 2017-2018, with 30 speakers of Estonian as L1 with B1 or B2 proficiency in Russian. Based on the results from an earlier pilot study with three respondents, B1 was selected as the lowest proficiency in Russian that was sufficient for completing the Ukrainian tasks (Branets et al. 2019). The sample included 10 male and 20 female participants, and all were residents of Tallinn at the moment of testing. Their ages ranged from 22 to 59 years. Most of the participants were current university students in many different programs and disciplines. Seven participants had already completed higher education. 


\section{Results}

\section{I. C-TESTS: PILOT RESULTS}

Recall that we first carried out a pilot study to test the four most suitable texts to use in the C-test for the experiment. The pilot also gave us valuable information about which words were problematic for L2 speakers. We found that the items that gave L2 learners trouble can be classified into four categories. These include idioms, low-frequent words, adverbial participles, and words that show particular lexical or phonological differences from Estonian. We shall provide a few illustrative examples.

Non-native speakers of Russian were not familiar with some expressions and idioms:

(1)

Russian

предавался праздной жизни

predavalsja prazdnoy zhizni

'was luxuriating'/

'was leading a pleasure-oriented life'

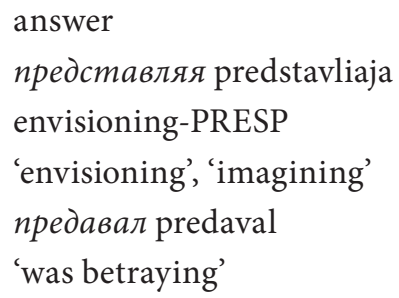

Only two respondents were able to recognise this idiom correctly, while two participants offered the answers cited above, and the rest left this item unanswered. The answer предавал predaval 'was betraying' sounds like the target word предавался predavalsja 'was leading' but has a completely different meaning.

Participants were not familiar with some low frequency words that were specific to the semantic domain central to a particular text, such as to the text on Egyptian archaeology: раскопки raskopki 'excavation', фараоны faraons 'Pharaohs', египетской jegypetskoy 'Egyptian', and rетописи letopisi 'Chronicle'. For native speakers such lexemes appeared to be easy.

Adverbial participles seemed to be the one grammatical category that was problematic. Respondents either gave no answer in (2) 
or recognised only the verbal root, settling on erroneous grammatical markers:

\begin{tabular}{|c|c|}
\hline Russian & answer \\
\hline nокрыты pokryty & покрыться pokryt'za \\
\hline covered-ADV PART, PL & to get covered-v, INF \\
\hline 'covered' & покрыто pokryto \\
\hline
\end{tabular}

Participants sometimes made use of variants based on Estonian that resemble the correct Russian word:

$\begin{array}{lll}\text { Russian } & \text { answer } & \text { Estonian } \\ \text { гигантское gigantskoje } & \text { гигантное gigantnoje } & \text { gigantne } \\ \text { 'huge' } & \text { гигантовое gigantovoje } & \text { 'huge' } \\ & \text { гигантише gigantishe } & \end{array}$

The first answer гигантное gigantnoje 'huge' is very similar to Estonian gigantne 'huge' and most probably was interpreted in such a way because of the similarity. Seven participants provided incorrect answers with non-existing words in Russian as presented in example 3 further below. At the same time, four respondents provided the correct answer: гигантское gigantskoje 'huge'.

Finally, words that are generally felt to be difficult to pronounce for Estonians appeared also to be difficult to recognize, e.g. изображения izobrazhenija 'image', прическа prichoska 'hairstyle'. In most cases respondents left blank spaces for such words.

\subsection{C-TEST ERRORS}

The general success rate in completing the Russian C-tests by speakers of Estonian was 66\%. In Section 4.3 below, we will explore the correlation between C-test scores and the scores on the Ukrainian tasks. However, we first report on information the C-test errors 
provide on which aspects of Russian prove difficult for L2 speakers, and would therefore be of little use when deciphering input in Ukrainian.

We start with the items that proved relatively difficult, defined here as items that scored under 15 points. This group ('Series 1' in diagram 1) contains 19 words, with scores between 7.75 and 14.75 (i.e. recognised correctly by fewer than half of the 30 participants). The second group ('Series 2') comprises 67 words, with scores ranging from 15.5 points to 29.75 .

Group $1 \square$ Group 2

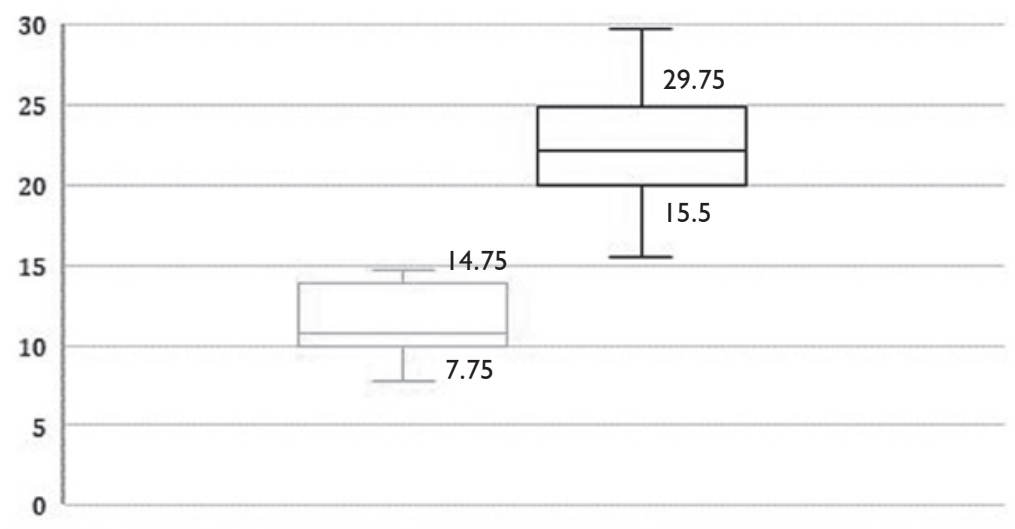

Diagram I. The division between low- and high-scoring words in the C-test.

We found that the group of words that received low scores contains mostly lexical elements that could well be unfamiliar to participants due to their low frequency or because they belong to specific semantic domains. Other words led participants astray because phonological and lexical similarity with Estonian made them assume more semantic similarity than there really is (false friends). Finally, there were words which were partially understood, as the root was recognized, but which were given erroneous grammatical marking. These findings confirm the findings from the pilot study, reported in Section 4.1 above. Below we present some more examples. 
The lowest score (7.75) was for термальные termal'nyje 'thermal', a word not widely used in everyday communication, and specific to domains related to recreation facilities. It is likely that many participants had not encountered this item before. They either left an empty space or offered non-existing words such as термальь termaly, терматологи termatologi, термательный termatelnyi, терманые termanyje.

Participants also experienced difficulties with the adverbial 'only', which received a score of 10.75 .

(4) Russian

answers

тищь lish'

либо libo

'only'

'either'

лищ lish, лиж lizh

The word лищь lish' 'only' had a functional role in the test sentence and is not commonly used this way in everyday speech. Six times, it was interpreted as либо libo 'either', probably because of its similar beginning. In five cases, it was misspelled and written as лиш lish or лиж lizh.

A common error in the C-test is to attach the wrong grammatical endings to a correctly identified root. This can be seen in the various ways in which the adjective богатымu bagatymi 'rich' was represented; this common word received a score of only 11.25.

(5) Russian

богатыми bagatymi rich-PL, INS 'rich' answer

богатами bagatami, богатьом bagatjom, богатными bagatnymi богатый bagatyi

rich-SG, NOM

богатым bagatym

rich-SG, INS

бozambı bagatyje

rich-PL, NOM

богатом bagatom

rich-SG, PREP 
In most cases, participants filled in non-existing words, such as богатами bagatami (seven times), богатными bagatnymi (one time) and богатьом bagatjom (one time). There were also many cases where the grammatical number and grammatical case were wrong. In the example, the correct choice would have been the plural and instrumental case богатыми bagatymi 'rich'.

The final example in this category concerns orthographic errors.

(6) Russian

$$
\begin{array}{ll}
\text { Russian } & \text { answers } \\
\text { надеяться nadejat'za } & \text { надеяиа nadejazha, } \\
\text { 'to hоре' } & \text { надеять nadejat', } \\
& \text { надеют nadejut, } \\
& \text { надеють nadejut', } \\
& \text { надеятса nadejatsa }
\end{array}
$$$$
\text { 'to hope' надеять nadejat', }
$$

With the word надеяться nadejat'za 'to hope' (score 14.75), participants had difficulties with orthography. They wrote this word as they would pronounce it for instance, надеяиа nadejazha or надеятса nadejatsa.

The group of words that received high scores contains many cases where some of the grammatical marking was wrong but the root word was identified correctly. The first example is мира mira 'world' (15.5):

(7) Russian мира mira world-GEN 'world' answers

мup mir

word-NOM

мupe mirje

world-PREP

мuгa miga

moment-GEN

'moment'

Six times the word was given in its nominative form and two times with prepositional case instead of correct genitive. The one participant who used the genitive filled in the incorrect stem мигa miga 'moment'. 
The final example presents a different kind of error: a misunderstood pronoun. Participants sometimes missed its lexical meaning completely; this word received a score of 22.5.

(8) Russian

такие takije

such-PL, NOM

'such'

\author{
answers \\ maкже takzhe \\ 'also' \\ maкu taki \\ still-PTCL \\ 'still', 'after all' \\ таким takim \\ such-M, IST, SG \\ maкое takoje \\ such-N, NOM, SG
}

Misunderstood function words can keep L2 speakers from understanding the input, perhaps more so than recognized content word stems of which the grammatical marking is misunderstood. Five times this word was interpreted as maкжe takzhe 'also', which has a completely different meaning. One participant mistook it as equally incorrect таки taki 'still', 'after all'. Two participants were confused concerning grammatical case and number and instead of plural used singular, neuter maкoe takoje 'such' and also instead of nominative used instrumental and masculine таким takim 'such'.

The few times that functional words were target items in the C-test did not yield exceptionally high scores (74.4\% versus $64.4 \%$ for content words). This suggests that, despite high frequency, misunderstood function words can contribute to compromised understanding in an L2, alongside the other three main sources documented in our analysis above: unknown lexical items, missed grammatical markers, and spelling errors. We now turn to the question of whether problems encountered in the C-test correlated with problems experienced in the Ukrainian tasks. 


\subsection{THE EFFECT OF C-TEST SCORE ON UKRAINIAN SCORES}

In this section, we present the correlations between the participants' performance on the C-test in Russian and on the tasks testing their understanding of separate Ukrainian words and Ukrainian texts in general. Diagram ${ }^{1} 2$ presents the correlations per participant between the Russian C-test results and their results on the Ukrainian word recognition task. The correlation is quite strong: $r=0.74$, confirming our expectation. Better performance on the Russian C-test implies better recognition of Ukrainian words.

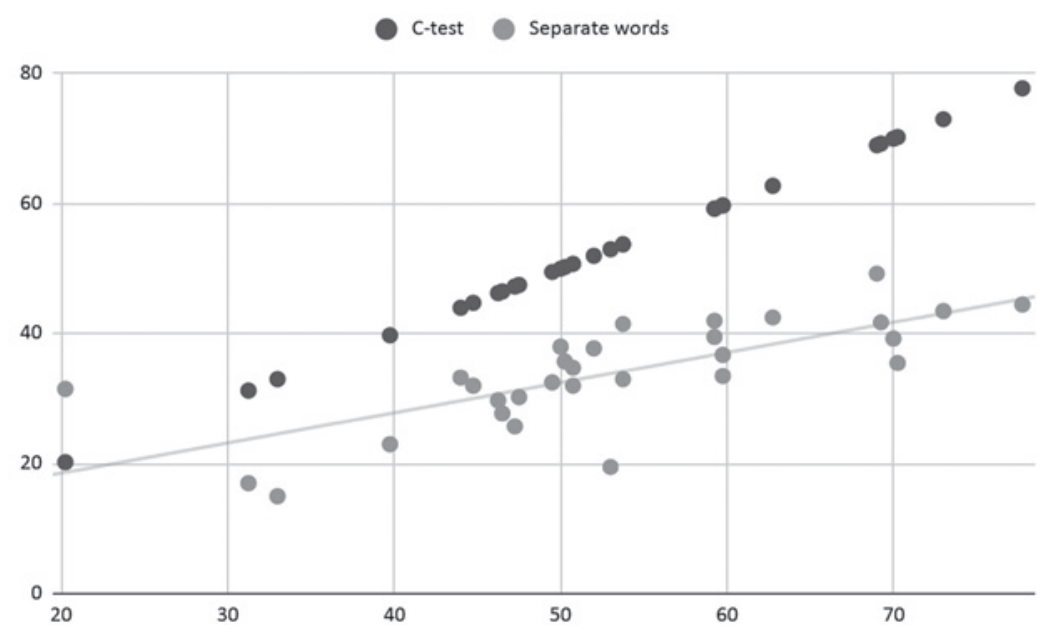

Diagram 2. Correlation between C-test results and word recognition tasks in Ukrainian.

Next, we compare the scores on the Russian C-test and the task testing general understanding of the Ukrainian texts (see Diagram 3 below). Note that the absolute scores are quite high, as 40 is the maximum score and many dots are above 30 , while there are none

\footnotetext{
1 Russian C-test scores in the scatter charts (Diagrams 2 and 3) are presented as $\mathrm{x}$-axis of independent variables from lower score to higher, while Ukrainian scores presented as dependent variables on the performance of the C-test in Russian.
} 
under 20. The correlation is positive ( $\mathrm{r}=0.56)$ but rather low compared to the correlation with word recognition. Our expectation that a higher C-test score in Russian will predict a higher score in general understanding of Ukrainian is only moderately confirmed. There is a better correspondence between an individual's scores on the C-test and the word test than between an individual's scores on the C-test and the content test. If we compare the data in the two diagrams, we observe that the correlation is positive in both cases; however, the points are more scattered in Diagram 3 below than in Diagram 2 above. Ukrainian content scores present a relatively straight line, which suggests that differences in performance on the C-test do not affect the content scores in Ukrainian all that much.

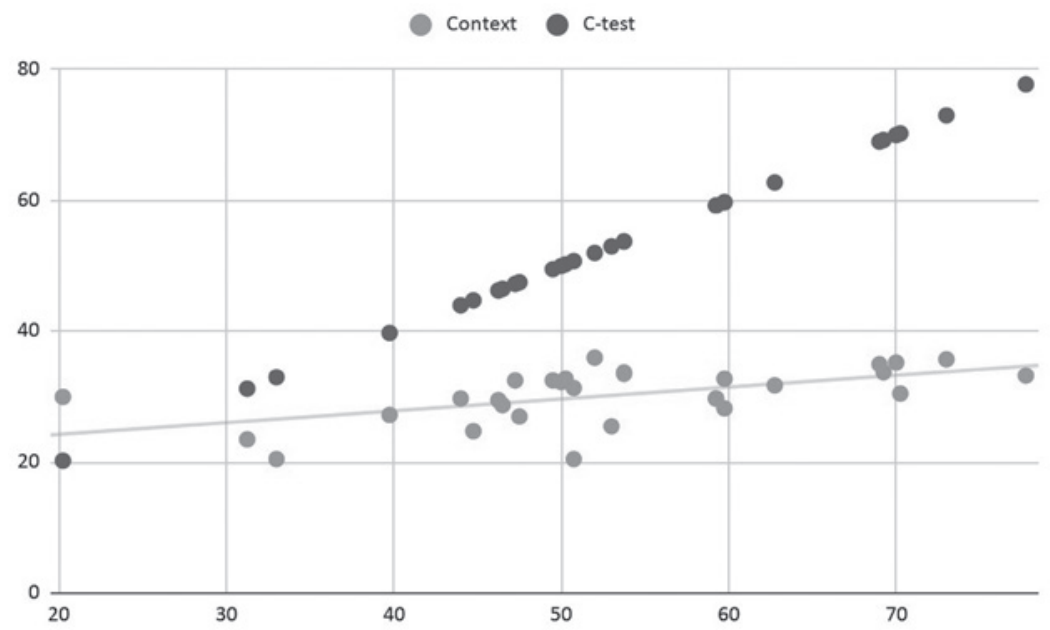

Diagram 3. Correlation between C-test results and content-related tasks in Ukrainian.

These findings support a previous investigation of understanding of Ukrainian by Estonians in Branets et al. (2019), which compared two L2 speaker groups with different proficiency levels. Estonians with B1 level, surprisingly, outscored participants with B2 level in understanding the context by $5.2 \%$, while participants with B2 level 
outscored those with B1 by $4.64 \%$ on the recognition of separate words in Ukrainian. Branets et al. (2019: 15) suggested that extralinguistic factors explained this difference: those with B1 had to try harder to compensate for their less advanced vocabulary knowledge.

To summarise, linguistic similarities between Russian and Ukrainian provide a strong basis for Estonian speakers when it comes to understanding Ukrainian. All presented correlation coefficients between the C-test in Russian and Ukrainian tasks are positive. This correlation is weakest for the content tasks, suggesting that C-tests are of relatively limited use in measuring overall language proficiency and that general receptive proficiency is driven by more than just lexical and grammatical knowledge. We discuss these implications below.

\section{Discussion and conclusion}

This paper reports on an empirical investigations of how useful it is to know an L2 when tasked with learning an L3 that resembles the L2. In a globalized world, the ability to make use of L2 knowledge when encountering new languages that have similarities with the L2 is a useful skill. We explored in particular whether the potential for L3 understanding in Ukrainian in these circumstances is simply a function of L2 proficiency in Russian by speakers of Estonian as L1.

Our results show that how Estonians performed on a Russian L2 C-test has some predictive value for how they performed on the two Ukrainian tasks they carried out. As expected, they also showed that this predictive value was better for a word recognition task than for a task testing general understanding of Ukrainian texts. Since the C-test tests lexical and grammatical knowledge, this result suggests that speakers made use of more than just their lexical and grammatical knowledge of L2 Russian to understand L3 Ukrainian. This is in line with the results outlined in Swarte et al. (2013), who report that the influence of L2 proficiency on L3 understanding is smaller when words are placed in sentential contexts. Context provides additional 
clues for participants to identify the correct semantics, avoid false friends, etc. (ibid: 154-155). During the debriefing interviews our participants reported that sometimes they relied more on the context than on linguistic clues provided by their knowledge of Russian (Branets, Verschik, accepted).

We used the C-test because it is a commonly used tool for measuring L2 proficiency. The expectation that a higher score on the C-test would predict a higher score on the Ukrainian tasks was indeed confirmed. Participants who have trouble recognising which words need to be filled in in the Russian L2 C-test also had trouble with recognising the meaning of Ukrainian words, presumably because their limited lexical and grammatical knowledge of Russian interfered with their ability to use their Russian knowledge for deciphering the meaning of the Ukrainian words they encountered. The reason for this is suggested by the results of our analysis of the C-test errors, which showed there were four main categories of problem sources. First, words with low frequency, including idioms and figurative expressions, sometimes proved unfamiliar. Second, incorrect grammatical markers were added to correctly identified stems. Third, spelling errors led to lower scores. Finally, function words occasionally presented problems and then were not recognised at all. It is likely that these limitations also caused the participants problems when faced with unfamiliar Ukrainian, as the Ukrainian counterparts of the problematic lexical items and grammatical morphemes will also not be recognised easily or at all.

However, it is interesting that the correlation between C-test scores and overall Ukrainian text understanding was much lower than that between C-test score and Ukrainian word recognition. Presumably, this relates to the degree to which C-tests rely on lexical and grammatical knowledge. However, it also points to limitations of the degree to which traditional tests of linguistic proficiency can predict general receptive ability, operationalized here as general text understanding. Obviously, to learn a foreign language it is important to learn words and grammar, but there are other factors at play as 
well, and the difference between the two correlations points to that. If the lexical and grammatical knowledge tested by C-tests were all important, it should determine overall understanding as much as it does lexical and grammatical knowledge. Perhaps, when a learner is faced with input, the unrecognised details that grammar provides can often reliably be filled in on the basis of context and knowledge of the surrounding content words, or even be ignored without too many consequences. Recognising content words makes it possible to activate knowledge of the world, and bring it to bear on the current communicative situation one is in. Learners tend to attend to lexical items more than grammatical items, presumably because nouns carry more important value when you try to deduce the meaning of what you hear or read (Spada, Lightbown 2008).

Of course, missing out on grammatical information can easily lead to comprehension problems, but in actual conversation these can be sorted out interactionally, especially if the degree of understanding is far from zero. As Firth and Wagner (1997: 288-289) pointed out, successful communication in a foreign language can be achieved even with limited communicative resources. Harmer (2001: 84-85), emphasising the communicative approach in language learning, encourages teachers to involve learners in natural communication, and treat successful communication as the target, rather than grammatically accurate language use. Our results support that general stance, since the correlation between C-test score and general understanding was not particularly high. From this perspective, successful understanding is likely to be boosted if the atmosphere is convivial and interlocutors are ready to help each other. This allows them to identify any emerging misunderstanding, and to practice ways of resolving the same. Branets et al. (2019) listed various extra-linguistic factors that affected understanding, such as exposure to Russian, exposure to different registers, experience with different multilingual situations, metalinguistic awareness, and language attitudes toward Ukrainian. It is likely that these factors help bring about the conviviality alluded to above. The current design, 
however, did not allow us to test this systematically, since it did not feature interactions in which participants had to actually converse with someone who was using Ukrainian. During the debriefing interviews, participants reported that it was familiarity with general knowledge and the context that helped them to comprehend Ukrainian texts better and recognise the unknown lexemes in Ukrainian by guessing or making assumptions that turned to be successful (Branets, Verschik, accepted).

Our results indicate that a C-test score does not predict a participant's ability to understand the Ukrainian texts very well, while it does do a good job of predicting their recognition of individual Ukrainian words, a task that is arguably closer to what one is asked to do in a C-test. These findings suggest that more is needed than L2 lexical-grammatical knowledge to understand texts in an unfamiliar L3 that is typologically similar to the L2. C-test scores have a built-in bias towards grammatical accuracy and it is striking that the higher grammatical competence that a high score on the C-test implies does not automatically mean that participants understand the Ukrainian texts any better. Note, however, that the absolute scores on the general understanding task were quite high, so further research is needed to explore the relationships between lexical and grammatical knowledge and the ability to achieve general text understanding. This ties in with the debate in SLA research on how much importance should be given to grammar in language teaching. There is some evidence that suggests that a focus-on-forms approach is valid as long as it includes an opportunity for learners to practise behaviour in communicative tasks. Grammar instruction should take the form of separate grammar lessons (a focus-onforms approach) but should also be integrated into communicative activities (a focus-on-form approach). An argument that cautions against too much explicit grammar teaching is that learners can and do learn a good deal of grammar without it being explicitly taught (Ellis 2006). Research on immersion programmes (e.g., Genesee 1987) also shows that learners in such programmes are able to 
develop the proficiency needed for fluent communication without any formal instruction in the L2.

Using an already existing multilingual repertoire as well as learning how to make use of the assistance interlocutors can provide each other, and how to enhance the learning possibilities this affords, are key factors in the learning process. We hope our study encourages further study that approaches language learning as learning how to communicate in a new context, rather than just the learning of words and grammar.

\section{REFERENCES}

Alcón, Eva; Usó, Ester 1998. Spoken discourse and second language learning (11-24). - Current Issues in English Language Methodology. Eds. Eva Alcon, Victoria Codina. Castellón de la Plana: Universitat Jaume.

Baghaei, Purya 2011. Optimal Number of Gaps in C-Test Passages. - International Education Studies 4, 1, 166-171. https://doi.org/10.5539/ies. v4n1p166.

Bahtina-Jantsikene, Daria 2013. Mind Your Languages: Lingua Receptiva in Estonian-Russian Communication. Utrecht: LOT.

Bardel, Camilla; Falk, Ylva 2007. The role of the second language in third language acquisition: The case of Germanic syntax. https://doi.org /10.1177/0267658307080557.

Block, David 2003. The Social Turn in Second Language Acquisition. Washington: Georgetown University Press.

Branets, Anna; Bahtina, Daria; Verschik, Anna 2019. Mediated receptive multilingualism: Estonian Russian-Ukrainian case study. - Linguistic Approaches to Bilingualism, 1-31. https://doi.org/10.1075/lab.17079.ver. Branets, Anna; Verschik, Anna (accepted). Comprehension of Ukrainian by Estonians via Russian: structural and extra-linguistic aspects. - Russian Journal of Linguistics 4.

Brouwer, Catherine E. 2003. Word searches in NNS-NS interaction: opportunities for language learning? - Modern Language Journal 87, 4, 534-45.

Brouwer, Catherine E.; Rasmussen, Gitte; Wagner, Johannes 2004. Embedded corrections in second language talk. - Second Language Conversations. Eds. Rod Gardner, Johannes Wagner. London: Continuum, 75-92. 
Brouwer, Catherine. E.; Wagner, Johannes 2004. Developmental issues in second language conversation. - Journal of Applied Linguistics 1, 1, 29-47.

Cenoz, Jasone; Genesee, Fred 1998. Psycholinguistic perspectives on multilingualism and multilingual education. - Beyond Bilingualism: Multilingualism and Multilingual Education. Eds. Jasone Cenoz, Fred Genesee. Clevedon: Multilingual Matters, 16-32.

Cenoz, Jasone; Jessner, Ulrike 2000. English in Europe: The Acquisition of a Third Language. Clevedon: Multilingual Matters.

Cenoz, Jasone 2001. The effect of linguistic distance, L2 status and age on crosslinguistic influence in third language acquisition. - Cross-linguistic influence in third language acquisition: psycholinguistic perspectives. Eds. Jasone Cenoz, Britta Hufeisen, Ulrike Jessner. Clevedon: Multilingual Matters, 8-20.

Cenoz, Jasone 2003. The role of typology in the organization of the multilingual lexicon. - The multilingual lexicon. Eds. Jasone Cenoz, Britta Hufeisen, Ulrike Jessner. Dordrecht: Kluwer, 103-16.

Chapelle, Carol A. 1994. Are C-tests valid measures for L2 vocabulary research? - Second Language Research, 10, 157-87. https://doi.org/10. 1177/026765839401000203.

Eskildsen, Søren W. 2019. Learning behaviors in the wild: How people achieve L2 learning outside of class. - Conversation Analytic Research on Learning-in-Action: The Complex Ecology of Second Language Interaction 'in the wild'. Eds. John Hellermann, Soren W Eskildsen, Simona Pekarek Doehler, Arja Piirainen-Marsh. Dordrecht: Springer, 105-129.

Ellis, Nick C. 2006. Selective Attention and Transfer Phenomena in L2 Acquisition: Contingency, Cue Competition, Salience, Interference, Overshadowing, Blocking, and Perceptual Learning. - Applied Linguistics 27, 2, 164-194. https://doi.org/10.1093/applin/aml015.

Firth, Alan; Wagner, Johannes 1997. On Discourse, Communication, and (some) Fundamental Concepts in Second Language Acquisition Research. - Modern Language Journal 81, 3, 285-300.

Firth, Alan; Wagner, Johannes 2007. Second/Foreign Language Learning as a Social Accomplishment: Elaborations on a Reconceptualized SLA. - 
The Modern Language Journal 91, 1, 800-819. https://doi.org/10.1111/ j.1540-4781.2007.00670.x.

Fisher, Robert. A. 1984. Testing Written Communicative Competence in French. - The Modern Language Journal 68, 1, 13-20. JSTOR. https:// doi.org/10.2307/327688.

Flynn, Suzanne; Foley, Claire; Vinnitskaya, Inna 2004. The CumulativeEnhancement Model for Language Acquisition: Comparing Adults' and Children's Patterns of Development in First, Second and Third Language Acquisition of Relative Clauses. - International Journal of Multilingualism 1, 1, 3-16. https://doi.org/10.1080/14790710408668175.

Genesee, Fred 1987. Bilingualism and Language Disability. - Journal of Language and Social Psychology 6, 2, 147-149. https://doi.org/10. 1177/0261927X8700600209.

Gooskens, Charlotte 2013. Experimental methods for measuring intelligibility of closely related language varieties. - Handbook of sociolinguistics. Eds. Robert Bayley, Richard Cameron, Ceil Lucas. Oxford: Oxford University Press, 195-213.

Grotjahn, Rüdiger 1987. How to construct and evaluate a C-test: A discussion of some problems and some statistical analyses. - Taking Their Measure: The Validity and Validation of Language Tests. Eds. Rudiger Grotjahn, Christine Klein-Braley, Douglas K. Stevenson. Bochum: Brockmeyer, 219-253.

Hammarberg, Björn 2001. Roles of L1 and L2 in L3 Production and Acquisition. - Cross-Linguistic Influence in Third Language Acquisition: Psycholinguistic Perspectives. Eds. Jasone Cenoz, Britta Hufeisen, Ulrike Jessner. Clevedon: Multilingual Matters, 21-41.

Harmer, Jeremy 2001. The practice of English language teaching. Essex, England: Longman.

Leung, Yan-Kit I. 2005. L2 vs. L3 initial state: A comparative study of the acquisition of French DPs by Vietnamese monolinguals and CantoneseEnglish bilinguals. - Bilingualism: Language and Cognition 8, 1, 39-61. https://doi.org/10.1017/S1366728904002044.

Long, Michael H. 1981. Input, Interaction, and Second-Language Acquisition. - Annals of the New York Academy of Sciences 379, 1, 259-278. https://doi.org/10.1111/j.1749-6632.1981.tb42014.x. 
Odlin, Terence 1989. Language transfer: Cross-linguistic influence in language learning. Cambridge, UK: Cambridge University Press.

Oller, John W. 1970. Transformational Theory and Pragmatics. - The Modern Language Journal 54, 7, 504-507. JSTOR. https://doi.org/ $10.2307 / 321771$.

Rehbein, Jochen; Thije, Jan D. ten; Verschik, Anna 2011. Lingua receptiva (LaRa) - remarks on the quintessence of receptive multilingualism. - International Journal of Bilingualism. https://doi.org/10.1177/ 1367006911426466.

Ringbom, Hakan 1987. The Role of L1 in Foreign Language Learning. Clevedon: Multilingual Matters.

Ringbom, Hakan; Jarvis, Scott 2009. The importance of cross-linguistic similarity in foreign language learning. - Eds. Michael H. Long, Catherine J. Doughty. Handbook of Language Learning. Oxford: Blackwell, 106118.

Shumarova, Nataliia 2000. Мовна компетенція особистості в ситуації білінгвізму [Individual linguistic competence in the situation of bilingualism (Ukr.)]. Куiv: Видавничий центр КДЛУ.

Sloboda, Marián; Brankačkec, Katja 2014. The mutual intelligibility of Slavic languages as a source of support for the revival of the Sorbian language. - Sprachminderheiten: gestern, heute, morgen / Minoranze linguistiche: ieri, oggi, domani. Eds. Ludwig Fesenmeier, Sabine Heinemann, Federico Vicario. Frankfurt am Main: Peter Lang, 25-44.

Spada, Nina; Lightbown, Patsy M. 2008. Form-Focused Instruction: Isolated or Integrated? - TESOL Quarterly 42, 2, 181-207. JSTOR. https://doi. org/10.2307/40264447.

Swarte, Femke; Schüppert, Anja; Gooskens, Charlotte 2013. Do speakers of Dutch use their knowledge of German while processing written Danish words? - Linguistics in the Netherlands 30, 1, 146-159. https://doi. org/10.1075/avt.30.11swa.

Tyshchenko, Kostyantyn 2010. Всеслов’янські складники української мови [Pan-Slavic components of Ukrainian (Ukr)]. - Ternopil: Мандрівець: всеукраїнський науковий журнал, 3, 65-75.

Wagner, Johannes 2004. The classroom and beyond. - The Modern Language Journal, 88, 612-616. 


\section{K2 OSKUS SOODUSTAMAS K3 OMANDAMIST: VENE KEELE ROLL EESTI KEELT ESIMESE KEELENA KÕNELEJATEL UKRAINA KEELE MÕISTMISES}

Artikkel vaatleb empiirilistele andmetele toetudes seda, kuidas eesti emakeelega inimeste vene keele kui teise keele oskus võib kergendada ukraina keele kui kolmanda keele passiivset oskust. Kolmekümne eesti keelt emakeelena kõneleva inimesega viidi läbi katse, mille käigus tuli neil kõigepealt täita sotsiolingvistiline küsimustik, seejärel teha läbi C-test vene keeles ning seejärel katse ukraina keelt puudutav osa, mille käigus vaadeldi seda, kuidas nad saavad aru ukrainakeelsetest sõnadest ja tekstidest. Pärast viimast ülesannet oli vastanutel võimalus anda tagasisidet. Uurimuses pöörati põhitähelepanu sellele, kuidas on seotud vastajate vene keele C-testi tulemused ukrainakeelsete sõnade ja tekstide mõistmisega. Autorid toovad välja ka kõige lihtsamaks ja kõige keerulisemaks osutunud grammatiliste ja leksikaalsete vahendite loendi. Tulemused näitasid, et vene keele C-testi ja ukrainakeelse katseülesande tulemused olid seotud. Ukrainakeelsete tekstide mõistmine oli siiski pisut vähem vene keele testi tulemustega seotud kui üksikute sõnade mõistmine. See näitab, et C-testi tulemused ei ennusta katsealuste võimet täielikult mõista ukrainakeelseid tekste, pigem ennustab C-testi hea tulemus võimet mõista üksikuid ukrainakeelseid sõnu. Saadud tulemuste põhjal võib väita, et keeleõppijad kasutavad teise keelega sarnase kolmanda keele tekstide mõistmisel ka neid ressursse, mis ei põhine grammatilistel ja leksikaalsetel teadmistel teise keele kohta.

Võtmesõnad: vahendatud retseptiivne mitmekeelsus, mõistmine, kolmanda keele omndamine, C-test, ukraina keel, vene keel, eesti keel 
Anna Branets is a PhD student at the University of Tartu. Her research interests comprise such topics as sociolinguistics, multilingualism and namely receptive multilingualism, comprehension between languages, L3 language acquisition. anna.branets@ut.ee

Ad Backus is a Professor in the Department of Culture Studies at Tilburg University, Netherlands. Research interests include language contacts, multiculturalism, communication and language use.

a.m.backus@tilburguniversity.edu 